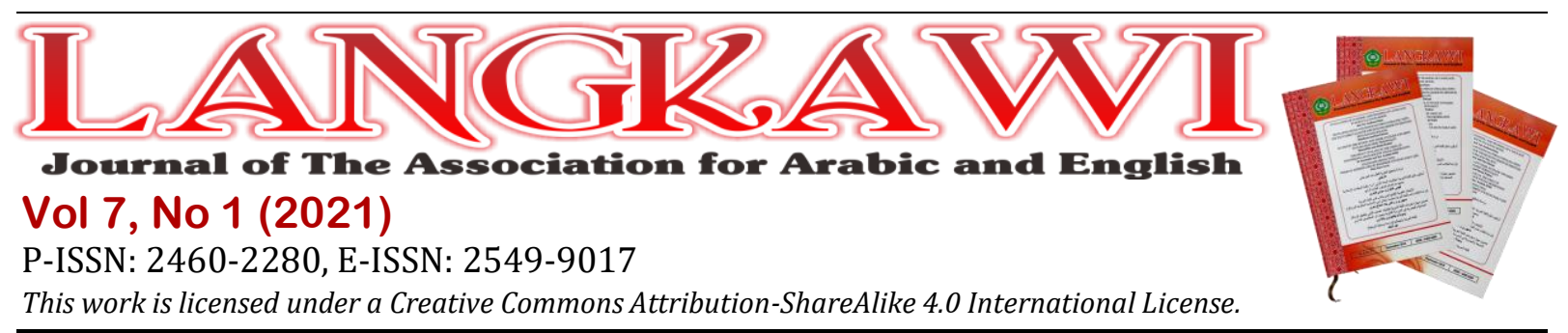

\title{
Learner Autonomy in EFL Online Classes in Indonesia: Students' Voices
}

\author{
Rolisda Yosintha' ${ }^{1}$, Sukma Shinta Yunianti ${ }^{2}$ \\ 1Universitas Tidar, Indonesia. E-mail: rolisda@untidar.ac.id \\ ${ }^{2}$ Universitas Tidar, Indonesia.E-mail: sukmashinta@untidar.ac.id
}

\begin{abstract}
ARTICLE INFO
Keywords:

Autonomous learning;

EFL; Learner autonomy;

Online learning

How to cite:

Yosintha, R., Yunianti,

S. S. (2021). Learner

Autonomy in EFL

Online Classes in

Indonesia: Students'

Voices. Langkawi Journal

of The Association for

Arabic and English, 7(1),

119-133.

DOI:

http://dx.doi.org/ 10.31332/lkw.v7i1.2637

History:

Received: 2021-03-04

Accepted: 2021-06-21

Published: 2021-06-24

ABSTRACT

While learner autonomy has proved to be one of the determinants of successful language learning, little has been scrutinized when implemented in EFL online learning settings. This study aimed to investigate learner autonomy in English as a Foreign Language (EFL) online classes as viewed from the students' standpoints. Through a mixed-method approach, the researchers collected data both quantitatively and qualitatively using questionnaires and interviews. As many as 513 students from 8 universities across Indonesia filled out the questionnaires, and 10 of them were interviewed to corroborate the findings. The quantitative data were converted into percentages, while the qualitative ones were analyzed using content analysis by categorizing them into themes, coding, and evaluating to find connections. The findings show that most students (80.5\%) had positive attitudes towards their autonomy during English online learning, as indicated in their motivation to be self-reliant. Even so, this positive attitude did not imply satisfactory learning outcomes, for there were only $18.5 \%$ of the students who got an A in their English course. To make learner autonomy impact achievement, lecturers could take pedagogical measures, such as encouraging peer-tutoring, selecting interesting and easy-to-use online learning platforms, and implementing the Project-Based Learning model. These findings imply that teachers should be more thoughtful in selecting learning activities and settings that could stimulate the development of learner autonomy.
\end{abstract}

\section{Introduction}

In the realm of English as a Foreign Language (EFL) education, the notion of learner autonomy (LA) has gained a central place. It is because LA has been proved to be one of the driving factors affecting success in EFL learning (Hsieh \& Hsieh, 2019; Liu, 2016; Rahman \& Suharmoko, 2018; Tayjasanant \& Suraratdecha, 2016; Tran, 2020). Undoubtedly, having autonomy greatly contributes to success in EFL learning (Hsieh \& Hsieh, 2019; Koirala, 2020; Orawiwatnakul \& Wichadee, 2017; Tayjasanant \& Suraratdecha, 2016; Tran, 2020). There are some reasons behind this common agreement. First, learner autonomy lifts motivation, particularly the intrinsic one, to meet their learning needs autonomously. Intrinsically motivated students would perform their learning activities for the pleasure of learning, not for external rewards. They would control and make choices for their own learning. In the end, they would 
know that the results of their learning, either success or failure, are attributed to their own hard work and approaches to learning rather than to some other aspects outside their control. Second, when students are motivated and able to evaluate their strengths and weaknesses, their learning process would be more effective and efficient. Consequently, the level of success in their learning outcomes would depend on the degree of their autonomy. Third, the development of procedural skills impacts success in attaining communicative competencies. Likely, these skills cannot be developed to the full range when learned in a classroom setting (Little, 2003). Therefore, with their high degree of autonomy, autonomous learners would show more willingness and get more chances to develop their communicative competence through direct use outside the classroom setting than those with low autonomy.

The majority of studies have confirmed the importance of stressing learner autonomy in EFL learning, either offline or online learning modes. Liu (2016), Orawiwatnakul and Wichadee (2017), and Koirala (2020) have explored the implementation of autonomous learning through various treatments in different offline learning contexts. They affirm that students who learned autonomously showed higher remarks than those learning traditionally. This achievement could be improved by giving sufficient training in autonomous learning strategies. In addition, they suggested that students with high English proficiency tended to have firmer beliefs in autonomous learning. As for the constraints, unsupportive cultural perception of teaching and learning preferences hinder autonomy in learning and thus hamper their English acquisition. These studies suggested that teachers should take into account students' readiness to learn autonomously and provide sufficient scaffolding to bridge the gap between students' cultural backgrounds and the expected instructional practices. Not only in a conventional classroom setting, but studies on LA were also carried out in "out-of-class" environments such as in selfaccess centers (Hsieh \& Hsieh, 2019), in virtual classes (Bedoya, 2014), and a hybrid learning setting (Shams, 2013). They confirmed that confidence and independence during learning play significant roles in students' achievement in the "out-of-class" environments. Furthermore, they reported that this accomplishment was also affected by teachers' roles concerning the development of course design and platform selection. In this learning environment, students were encouraged to be self-reliant, responsible, cooperative, and active during the learning process.

In the Indonesian EFL setting, however, studies concerning learner autonomy are limited to those carried out synchronously in conventional or offline classes and to those viewed from the teachers' perspectives (Darsih, 2018; Lengkanawati, 2017; Sholihah et al., 2019; Wiraningsih \& Dewi, 2020; Yuzulia, 2020). Lengkanawati (2017) investigated EFL teachers' perceptions regarding LA and their responses to training held to stimulate the implementation of LA in their classes. It was found that the teachers in this study believed that learner autonomy did not mean learning without teachers. Even though many LA principles were not that practicable in their situation, LA was highly desired to be implemented in the teaching and learning activities. The findings also identified several constraints that hindered the development of LA among Indonesian EFL students, namely students' lack of LA experiences, unsatisfactory English proficiency, and too much concentration on the national examination. In another study, Darsih (2018) explored lecturers' belief in LA and the 
teaching and learning activities they implemented to foster LA. Through an exploratory study using questionnaires and interviews, the researcher found out that despite the lecturers' efforts to stimulate LA during the course, the students' LA level was unsatisfactory.

Studies on LA in Indonesian EFL settings have also been conducted in school contexts, but still, they focused on LA implementation in traditional or offline classes and were analyzed from the teachers' viewpoint (Wiraningsih \& Dewi, 2020; Yuzulia, 2020). Their studies revealed that teachers believed that students had active roles in managing their own learning in autonomous learning. Also, they agreed that employing such media as blogs, self-journals, videoconference, and collaboration would promote learner autonomy and thus positively affect their learning outcomes. Meanwhile, in terms of the roles they play during the implementation of LA, teachers tended to act as facilitators, organizers, counselors, and resources. Teachers were expected to involve students in determining the learning objectives, managing the classroom, and selecting the learning materials.

As mentioned earlier, many studies have discussed learner autonomy in the Indonesian EFL setting, particularly those run in offline modes, and focused on teachers' viewpoints. However, studies that specifically investigate the implementation of LA in Indonesian offline learning contexts and that are viewed from the students' perspectives are rarely found. With the rapid growth of technology and the widening opportunities for pursuing higher education, there is a huge demand for a more flexible learning model in which students can have more independence to manage their own learning from anywhere and at any time. Given this motive and considering this research gap, a study on learner autonomy in Indonesian EFL online classes becomes an insistent need. Therefore, the current study is guided by the following research questions: 1) What is the students' attitude towards learner autonomy in EFL online classes in Indonesia? 2) What is the students' attitude towards teacher's and peer's roles in EFL online learning? and 3) What measures could be taken to boost learner autonomy? The findings of this study are expected to contribute to the betterment of the implementation of online learning in Indonesia in terms of the development of students' autonomy. Particularly, teachers can use this study as a reference when designing classroom activities and developing the learning materials that could facilitate the development of learner autonomy.

\section{Method}

The present study investigated learner autonomy in online EFL settings as viewed from the students' perspectives and examined the most viable actions to foster learner autonomy. To meet these two objectives, the current study employed a mixedmethod approach. Creswell and Creswell (2017) assert that a mixed-method research design aims to better understand an issue by collecting, analyzing, and integrating both quantitative and qualitative studies in a single study. This method was chosen since this study intended to investigate two aspects that will complete and confirm one another's results.

The research participants were 513 students who had experience in studying English as a foreign language online. On average, they had experience in learning English online for at least 6 (six) months. They were from 8 (eight) universities across Indonesia with various majors. A convenience sampling technique was used to select 
these participants, meaning that students who were conveniently available to participate in the study could be selected. Since this study was related to personal perspectives, the researchers asked for the participants' consent before the data collection. In addition, the data they gave were submitted anonymously to make sure that the information they provided was not linked to them.

To gain robust foundations for the findings and support arguments, the data were triangulated and collected quantitatively and qualitatively through questionnaires and interview. The questionnaire was intended to obtain a description of the students' performance in their online EFL classes and identify the manifestation of their autonomy as reflected in their behaviors. This questionnaire was distributed online using Google Form at http:/ / bit.ly/ AutonomyEFL. There were two parts to the questionnaire: personal information (Part A) and learner autonomy in EFL online learning (Part B). Part A (6 items) examined students' sex, age, university, major, semester, and months of attendance in EFL online instruction. Part B (25 items) explored the students' attitudes towards learner autonomy in EFL online learning. Each item in this part was weighted $1-4$ based on the four Likert Scale options: Never, Seldom, Sometimes, and Always. For strengthening the findings, a semi-structured interview with 10 (ten) students was conducted online. These students were chosen as a representative sample of the group considering their performance during the EFL course. As many as 6 (six) male and 4 (four) female students participated in the interview. They were aged 18-21 years old and were from 4 (four) different universities. For protecting the interviewees' confidentiality, pseudonyms were given. Table 1 shows the demographic information of these interview participants.

Table 1. Partisipants' demographic information

\begin{tabular}{cccc}
\hline Participant & Pseudonym & Sex & Age (Years Old) \\
\hline 1. & Student A & Male & 18 \\
2. & Student B & Male & 19 \\
3. & Student C & Female & 18 \\
4. & Student D & Male & 20 \\
5. & Student E & Female & 21 \\
6. & Student F & Female & 18 \\
7. & Student G & Male & 18 \\
8. & Student H & Male & 19 \\
9. & Student I & Male & 19 \\
10. & Student J & Female & 19 \\
\hline
\end{tabular}

The data were analyzed both quantitatively and qualitatively. The data from the questionnaires were categorized into levels of frequency and converted into percentages. Meanwhile, the data obtained from the interviews were analyzed using content analysis to provide insights and understandings of the phenomena (Tight, 2017). In the process, the raw data were categorized into themes, coded, and analyzed 
to find connections. The results from both instruments were then compared to generate thorough findings.

\section{Findings and Discussion}

As mentioned earlier, the present study attempted to explore students' attitudes towards learner autonomy in EFL online learning in Indonesia. In addition, this study also tried to propose the most viable measures to be taken to foster learner autonomy in online learning settings. This section presents the findings of the study and elaborates them in a thorough discussion.

\subsection{General Attitudes towards Learner Autonomy in EFL Online Learning}

What are the students' attitudes towards learner autonomy in EFL online learning? To answer this question, first, the participants were asked to rate their general attitudes towards their autonomy when studying English in an online mode on a four-point scale, one being very negative and four being very positive. As shown in Table 2, the mean score for all responses given by 513 participants understudy was 3.1, meaning that most participants have a positive attitude towards learner autonomy in EFL online classes.

Table 2. General Attitudes towards Learner Autonomy in EFL Online Learning

\begin{tabular}{cccccc} 
Indicator & $\begin{array}{c}\text { Very } \\
\text { Negative }\end{array}$ & Negative & Positive & $\begin{array}{c}\text { Very } \\
\text { Positive }\end{array}$ & Mean \\
\hline $\begin{array}{c}\text { Rate your general attitude } \\
\text { towards learner autonomy in } \\
\text { studying English online. }\end{array}$ & 14 & 88 & 248 & 163 & 3.1 \\
\hline
\end{tabular}

This positive attitude is supported by some responses given in the questionnaire. First, as many as 413 students (80.5\%) showed positive attitudes towards their learning autonomy, as indicated by their high motivation in learning English online. Meanwhile, the rest, consisting of $10(1.9 \%)$ and 90 students $(17.5 \%)$, were highly unmotivated and unmotivated during the online learning respectively. The finding reveals that students with high motivation tend to have positive attitudes towards learning English in an asynchronous context similar to those of previous studies. For instance, a study found that students in Thailand felt motivated by the online learning model they never had before (Orawiwatnakul \& Wichadee, 2017). As they were motivated, they showed more interest in managing their own learning, such as in choosing topics to be learned and deciding on the types of learning activities they preferred. Students under this study also showed similar indicators of high autonomy in learning English online as those in Ahn's study (2017) that was carried out in Korea. As many as 389 students $(74.7 \%)$ could identify what materials they needed to learn to support their learning during the online instruction, 459 students (89.5\%) independently searched the Internet or other sources for learning materials, including books and exercises, that suited their proficiency levels and learning styles, and 285 students (55.6\%) were eager to learn English autonomously outside their regular English schedule. With high motivation, these students became more and more independent in learning, and thus their attitudes towards autonomous learning could increase gradually. Although most students in this study showed a positive attitude towards studying English online, their final score for the English course they took 
during the online learning mode was unsatisfactory. As shown in Figure 1, there were only $95(18.5 \%)$ out of 513 students who got an A for their English online course, while the rest got B (50.5\%), C (19.9\%), and D (11.1\%).

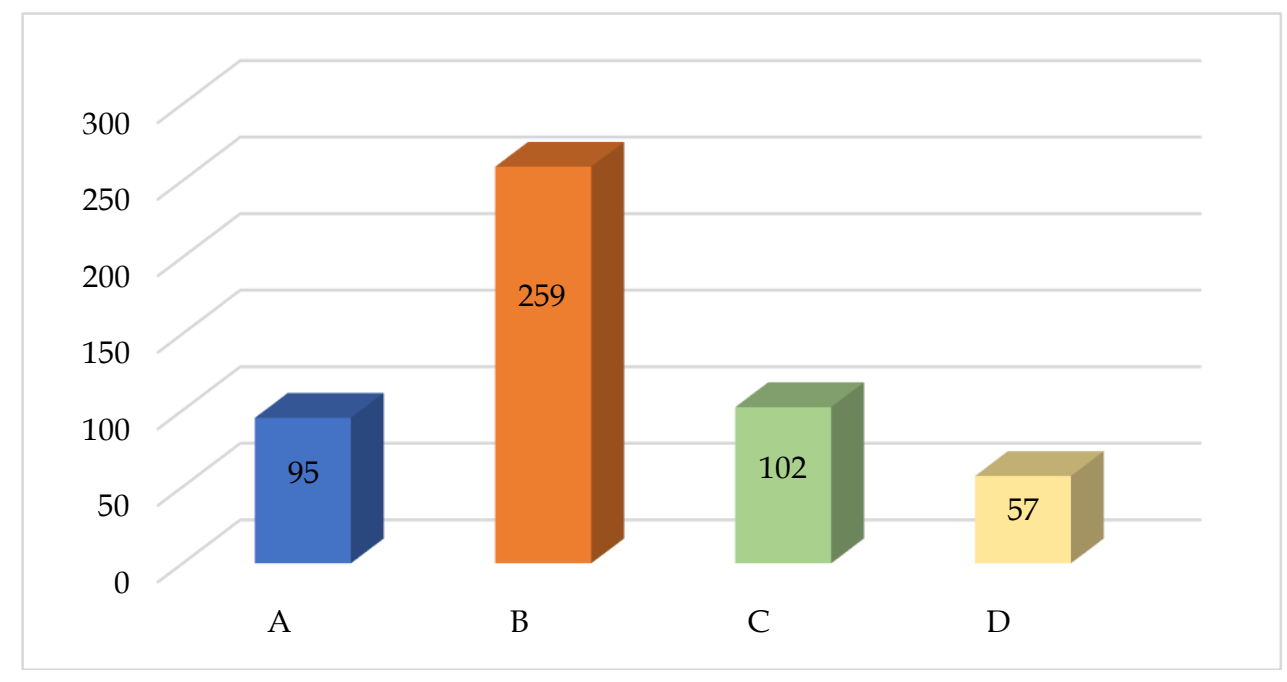

Figure 1. Students' Final Score for English Course during Online Learning

Concerning their English achievement as indicated by their final scores, students in this study affirmed that even though they had positive attitudes towards studying English online, and they believed that studying online helped them to be more autonomous in learning, they were positive that their achievement in English depended on their motivation and learning styles. Student C said,

"During the online classes, I found it difficult to study the materials on my own. I was used to listening to my teacher's explanation and taking notes during the class".

As a result of this inconvenience, her final score for the English course that she took during the online learning was not quite pleasing, whereas she demonstrated high learning autonomy during the course by trying to find extra materials from the Internet. She argued that her preferred learning styles could cause this. She was used to studying English in an offline mode with full assistance from her teacher, and she favored the auditory learning style in which the lecturer gave verbal presentations, and the students listened while taking notes during the class. She added that her lecturer tended to be a passive facilitator during online learning by simply providing the students with the materials and asking them to discuss them with their friends without directly explaining the subject matter, thus forcing them to shift their learning style. This inconvenience was also experienced by other students (Student $\mathrm{F}$ and $\mathrm{H}$ ), who mentioned that their autonomy while learning English online did not guarantee positive outcomes. They spent time studying English autonomously by watching online videos giving explanations on the topic, and they also actively discussed the materials with their peers. Even so, their English proficiency was not as expected. This finding confirmed that of Ahn (2017) in a study investigating Korean students' perception of online learning, stating that online learning did contribute to the development of autonomous learning; however, the learning outcomes would depend not only on motivation but also on learning styles. In addition to learning styles, responses given by the students under this study indicated that improper learning strategies during English online learning had also negatively affected their learning 
outcomes. As shown in Table 3, the mean score for learning strategies applied during online English instruction was 2.6. It indicated that these students find it quite difficult to adapt to the new learning mode and modify their learning strategies accordingly into autonomous learning.

Table 3. Students' Attitudes towards Autonomous Learning Strategies

\begin{tabular}{cccccc}
\hline Indicator & $\begin{array}{c}\text { Very } \\
\text { Negative }\end{array}$ & Negative & Positive & $\begin{array}{c}\text { Very } \\
\text { Positive }\end{array}$ & Mean \\
\hline $\begin{array}{c}\text { Rate your general attitude } \\
\text { towards autonomous learning } \\
\text { strategies in studying English } \\
\text { online. }\end{array}$ & 46 & 176 & 228 & 63 & 2.6 \\
\hline
\end{tabular}

This negative attitude towards the learning strategies they implemented during the online course was as indicated in some of their responses given in the questionnaire. First, nearly half of the students (240 out of 513) never or seldom reviewed the materials either before joining the class discussion or after the class. With a mean score of 2.5 for this indicator, it could not be said that they adequately show positive effort to remember and reengage to the information that had been learned. While "Reviewing" of which the final step in the SQ3R (Survey, Question, Read, Recall, and Review) was proved an effective learning strategy in increasing language skills, critical thinking skills, and motivation (Farris \& Werderich, 2019; Mangasi, 2019; Otto, 2014; Rice et al., 2019; Suganya, 2019), many students ignored the importance of this process.

In the interview session, Student J, D, E, H, and I mentioned that they reviewed their English materials only when they would face quizzes or tests. They did not allocate their time for this process simply because they did not feel like they need it.

"My lecturers never gave us English tests or quizzes without letting us know beforehand. So, I rarely reviewed the materials before the class. But when there would be tests or quizzes, I tried to review the materials to get a better score". (Student D)

On the other hand, Student A, B, C, E, F, G, and I, revealed that they regularly reviewed what they had learned before joining the class. This difference in attitudes towards reviewing process might be caused by the different driving factors that motivate students to learn. Those who favored the reviewing process tend to be intrinsically motivated in learning compared to those who often skip reviewing the materials. For example, Student G affirmed, "I always tried my best to have some time reviewing the materials before the class so that I can better understand the next materials faster. I believe that by making this effort, I can get a higher score as well". To better understand the materials and get a higher score in English were two prominent factors that pushed these students to review the materials before they joined the class. When students are intrinsically motivated, they will find the learning process more enjoyable and meaningful, and thus positively enforcing the development of learner autonomy (Bailey et al., 2020; Budiharto \& Amalia, 2019; Zouaidi \& Hermessi, 2019).

Second, concerning evaluating the learning process during the English online course, as many as 140 students $(27.3 \%)$ did not carry out a self-assessment of their 
learning performance. Even though the rest of the students $(72.7 \%)$ had selfassessment, in general, the students under this study could not be said to have a positive attitude towards their learning strategies, as shown with a mean score of 2.8 for this aspect. In the interview, even students who carried out a reviewing process before the class admitted that they hardly had a self-assessment. Student B affirmed

"I only read the materials. I've never self-assessed my performance. To me, when I already understand the materials, I can assume that I will perform better in any assessment types". (Student B)

Student $\mathrm{F}$ added that she was not familiar with the term self-assessment. All she knew was that what was called assessment was the kinds of tests given by teachers or lecturers during the learning process. She did not even know that students could have self-assessment to measure their performance independently. Self-assessment is a prevailing learning strategy in that students who can assess their own learning would seek feedback and information from other people or sources and then employ them to stimulate improvements (Andrade, 2019). Many studies have documented the importance of self-assessment when linked to learner autonomy (Ashraf \& Mahdinezhad, 2015; Gholami, 2016; Morales \& Mena, 2016; Schmidt \& Wehmeyer, 2016; Sukhenko, 2019) and confirmed that when students have clear goals, can identify their learning needs, self-assess their performance, and select the most effective strategies to reach those goals, they will reach betterment with meaningful motivation. In other words, through the self-assessment process, students can train their skills to be self-regulated learners who eventually will lead to learner autonomy.

Third, in terms of student engagement, as shown in their active participation during the virtual class meeting, it is indicated that the students under this study could not be said to have positive learning strategies. As shown in their responses to the questionnaire, a total of 140 students $(27.3 \%)$ never or seldom actively participated in the classroom discussion, and 373 students $(72.7 \%)$ sometimes and always showed active engagement. With a mean score of less than 3, i.e., 2.9, this indicator revealed that these students tended to be passive during online English instruction.

Student engagement during online learning should be incorporated as it is when carried out during traditional face-to-face instruction. In this study, however, the researchers found the unexpected. Through an interview, the researchers tried to identify the reasons behind this lack of active engagement. Student A asserted

"I rarely ask questions or give comments unless my lecturers ask me to do so. Even though I know the answer to the questions, I prefer not to speak up. I am just shy and unconfident to express my thoughts. My hesitation tends to increase when I speak up on the online meeting platform because usually the speaker's view will be spotlighted when he or she speaks. Usually, I speak up a little when the lecturers ask our general opinions of a topic". (Student A).

This statement reveals that shyness and lack of confidence do affect the students' active participation. Zhou and Chen (2020) already mention these two factors as the origins of class reticence that may cause teachers to lose their enthusiasm in teaching and students to learn almost nothing. Even with high proficiency, it is not a guarantee that a student will have the courage to take the lead to break the class silence. Furthermore, 
this result also confirms Zhou and Chen's findings (2020) that the types of questions or stimuli that the lecturers give to elicit students' responses affect the students' interest in speaking up in the discussion.

Another reason behind class reticence was revealed by Student C, emphasizing that encouragement from the lecturers to engage in the learning process actively was so important to boost students' active participation. She stated, "I never had the initiative to actively participate in class because my lecturer did not count participation in the grading schemes." Tharayil et al. (2018) found similar findings in their study. They revealed that grading students' participation could be an encouraging alternative to reduce their resistance. Through this strategy, students would be motivated to put aside their shyness or hesitation to express their thoughts, and thus the number of passive students could be decreased. Based on Student C's assertion, it could be inferred that incorporating participation into the grading schemes could be an effective stimulus for the students to participate in the teaching and learning process actively.

Even though the students in this study had positive attitudes towards learner autonomy while studying English online, they showed relatively low attitudes towards autonomous learning strategies, and it was proved by the mean score of the three aspects discussed earlier. Therefore, the findings of this present study confirmed that students' learning strategies during English online learning indicated the level of their autonomy as reflected in their habit of reviewing materials, selfassessment, and active participation during online learning. It was in line with what Zakaria et al. (2017) have investigated concerning the correlation between language learning strategies and learner autonomy among students studying Japanese in Malaysia. They found a significant correlation between the two aspects in that a higher level of autonomy would apply more learning strategies than those with lower autonomy.

\subsection{General Attitudes towards Lecturers' and Peers' Roles in EFL Online Learning}

Despite the lack of positive attitudes towards learning strategies in EFL online learning, it is confirmed in this study that students' attitudes towards the notion of learner autonomy in this context were relatively positive. For helping the researchers identify the right measures that could be taken to promote and maintain this positive attitude as well as to answer the second research question, it is necessary to investigate the students' attitudes towards their lecturers and peers during the English online learning so that the measures proposed could meet the students' needs and expectation towards a broader aspect of online learning.

In fact, the students under this study could not deny their needs for lecturers' and peers' assistance during online learning. As indicated in the questionnaire results, as many as $443(86.3 \%)$ out of 513 students mentioned that they still needed assistance from their lecturers and peers in carrying out the online learning process as well as in completing the assignments given by the lecturers. Meanwhile, the rest of the students (70) revealed that teachers' and peers' assistance was not needed during the English online learning. Yet, with a mean score of 3.41, these students have positive attitudes towards lecturers' and peers' support on average. Table 4 summarizes the students' responses on this aspect. 
Table 4. Students' Attitudes towards Lecturers' and Peers' Assistance

\begin{tabular}{cccccc}
\hline Indicator & $\begin{array}{c}\text { Very } \\
\text { Negative }\end{array}$ & Negative & Positive & $\begin{array}{c}\text { Very } \\
\text { Positive }\end{array}$ & Mean \\
\hline $\begin{array}{c}\text { Rate your general attitude } \\
\text { towards lecturers' and peers' } \\
\text { assistance in studying English } \\
\text { online. }\end{array}$ & 10 & 60 & 155 & 288 & 3.41 \\
\hline
\end{tabular}

This finding was similar to that of Lengkanawati (2017), stating that teachers' or lecturers' roles were considered a substantial contribution to create effective teaching and learning even in an independent learning context. However, autonomous learning does not imply learning in total independence without teachers' assistance. Teachers are mainly needed as resources, and in this English online learning context, they are most needed as facilitators (Wiraningsih \& Dewi, 2020). They make a plan to be implemented with the students and scaffold the teaching and learning process.

As facilitators, teachers or lecturers are expected to offer support and advice when they need it either in the synchronous or asynchronous learning mode. Student $\mathrm{H}$ affirmed,

"I don't hesitate to send a personal message to my lecturer to ask for anything that I don't understand yet. Luckily, she always replies to my message".

This kind of role is regarded as highly important by the students under this study. More than half of the students (330) expressed their need for lecturers' feedback and further explanation whenever they found something they did not understand yet.

In addition, peers' support and cooperation were considered indicators of positive attitudes towards learner autonomy. Not only from the lecturers, but the students in this present study also need some help and support from their peers, particularly when dealing with assignments. As many as 404 students $(78.8 \%)$ admitted that they could not stand alone without the support of their peers in some types of learning activities such as discussion and assignments. Even in an individual assignment, some students confessed that they still asked for help from their peers. Student G mentioned

"I don't cheat or ask the answers for the assignment. I just need my friends' opinions or sometimes explanations to help me better understand the materials to answer the questions. In that way, I could perform better on the task". (Student G)

This assertion indicates that peer teaching serves valuable benefits for students, particularly those who hesitate to consult their lecturers for help. This finding supports that of Meddas (2019) and Maarif (2020) that peer tutoring is perceived as effective in encouraging active learning as this process allows students to learn in more relaxed and enjoyable circumstances. Besides, peer tutoring promotes collaborative learning in which two or more students can work together to solve problems, learn new materials, or complete tasks. 


\subsection{Ways to Promote Learner Autonomy in EFL Online Learning}

To answer the second research question concerning the measures that could be taken to boost learner autonomy in EFL online learning, the researchers intensified the interview session with the ten participants to develop some solutions to be proposed as alternatives to enhance learner autonomy in this context. Three main ways could be projected to enhance autonomous learning in EFL online learning as summarized based on the responses of these participants, namely the enactment of peer tutoring activities, the use of engaging online learning platforms, and the implementation of Project-Based Learning (PBL).

First, as mentioned in the previous section, many students find it difficult to interact with their lecturers due to their hesitation. Peer tutoring could be proposed as an effective alternative to scaffold learner autonomy during English online learning to overcome this problem. The students cannot only have extra chances to reinforce what they have studied in the online meeting with their lecturers, but they can also learn more comfortably with no hesitation with their peers (Meddas, 2019). In that way, their autonomy in learning English online would gradually increase.

It is a good solution to enact peer tutoring as one of the learning strategies to be incorporated in the regular online teaching and learning activities with this potential. All students involved in the interview agreed that it is good to have peer tutoring sessions to make the learning activities varied and more enjoyable. Student D asserted, "Sometimes we get bored with the same learning activities in every meeting. So, I think peer tutoring can give us a new nuance so that we can keep motivated". For these reasons, lecturers should encourage the implementation of peer tutoring by regularly assigning some group activities for the students so that these students would be more confident, comfortable, and relaxed in sharing their ideas with their peers and working together to solve a task in a more autonomous manner.

Second, the participants mentioned interesting online learning platforms as one alternative to help them be more autonomous in learning English online. In fact, some students complained about the online learning platform that their lecturers used during online learning. Student J asserted

"The online learning platform provided by my university is not interesting. The user interface is dull with no bright colors. When we have our materials uploaded on this platform, I rarely accessed them unless it is required to do our assignments or quizzes".

This assertion indicates that learning platforms used by lecturers do affect students' interest in learning autonomously. When the platforms are interesting for the students, autonomy would be encouraged as they are stimulated to access and study the materials independently. Furthermore, accessibility is also considered as a factor that affects students' interest in learning English online. It is expected that the online learning platforms can be easily accessed anywhere and anytime (Albashtawi \& Al Bataineh, 2020; Istifci, 2016); however, some students under this study mentioned that the learning platforms used in their university often go down with some technical problems. It causes them to be late in submitting their assignments or in accessing the learning materials uploaded there by the lecturers. This inconvenience just added another problem to the implementation of EFL online learning. Therefore, the use of encouraging and easy-to-use online learning platforms is highly recommended to enhance students' educational outcomes. 
Third, Project-Based Learning (PBL) could be proposed as an effective learning model that best suits the characteristics of online learning. PBL advocates for a higher level of student-centeredness in which students are positioned as active participants in the teaching and learning process (Chen \& Yang, 2019). In PBL, students are encouraged to explore real-world problems and find solutions through investigation, collaboration, and experiment in a certain project. These activities could boost learner autonomy (Guo et al., 2020), which is particularly crucial in EFL online learning. Through PBL, students would have more responsibilities to take charge of their own learning. They are encouraged to unravel the real-life problems in their project, and thus they would be more engaged in the learning process and actively construct more knowledge on their own. Accordingly, their awareness of learner autonomy would increase as they become more self-reliant and autonomous in learning.

\section{Conclusion}

Autonomy has not been a typical attitude among Indonesian students, particularly in English as a Foreign Language (EFL) online learning. Even so, this present study has indicated that learner autonomy in this context is an inevitability and has proved to have a noteworthy effect on the outcomes of EFL online learning. It was revealed that most students under this study had positive attitudes towards learner autonomy in EFL online learning. They agreed that online learning demanded more autonomy and independence in learning. Even so, having this positive attitude did not guarantee to get a better learning outcome. In fact, most of the students participating in this study did not get an A for their English course. This unexpected result could be traced back to some potential problems related to their learning strategies. It was unfortunate that they did not yet implement learning strategies that reinforced learner autonomy, such as reviewing the learning materials, having a selfassessment of their performance, or showing active participation during the online learning.

To help improve this condition and make this positive attitude more beneficial for the students, the researchers propose three alternatives that are expected to improve learner autonomy. First, peer-tutoring should be enacted as a regular learning activity. It could be particularly advantageous for students who often hesitate to ask for their lecturers' help, and thus with their peers' help, they would not be left behind. Second, lecturers should carefully select the learning platforms to use during English online learning. It is suggested that the platforms should be interesting and easy to use to access the materials or assignments with no difficulties. Third, enhancing learning autonomy would be more effective when lecturers implement the Project-Based Learning model. Through projects related to real-world problems, the students would actively explore resources to build their understanding and thus encourage them to be more self-reliant. Because of the nature of the research participants, who were all selected from formal education contexts, further study could be extended to an informal learning setting so that the results could represent learner autonomy in EFL online learning in the Indonesian context. Also, research with follow-up interviews with a more significant number of participants could be carried out to provide a more comprehensive depiction of EFL students' attitudes towards studying English in online settings. Despite the limitations, the findings of this study carry pedagogical implications for teachers or lecturers. As facilitators in online learning, teachers or 
lecturers should realize that developing learner autonomy is not only the students' responsibility. Teachers should also take some measures to develop their awareness of the importance of learner autonomy to facilitate students' learning in such a way that stimulates autonomy.

\section{References}

Ahn, M. (2017). Student Perception of Language Achievement and Learner Autonomy in a Blended Korean Language Course: The Case Study of Defense Language Institute Foreign Language Center [Dissertation]. https://media.proquest.com/media/pq/classic/doc/4324866165/fmt/ai/rep /NPDF?_s=Z4OutJVR07rrABqECJv7Gqw5BnM\%3D

Albashtawi, A. H., \& Al Bataineh, K. B. (2020). The Effectiveness of Google Classroom Among EFL Students in Jordan: An Innovative Teaching and Learning Online Platform. International Journal of Emerging Technologies in Learning (IJET), 15(11), 78. https:// doi.org/10.3991/ijet.v15i11.12865

Andrade, H. L. (2019). A Critical Review of Research on Student Self-Assessment. Frontiers in Education, 4. https://doi.org/10.3389/feduc.2019.00087

Ashraf, H., \& Mahdinezhad, M. (2015). The Role of Peer-assessment versus Selfassessment in Promoting Autonomy in Language Use: A Case of EFL Learners. International Journal of Language Testing, 5(2), 110-120.

Bailey, D., Almusharraf, N., \& Hatcher, R. (2020). Finding satisfaction: Intrinsic motivation for synchronous and asynchronous communication in the online language learning context. Education and Information Technologies. https://doi.org/10.1007/s10639-020-10369-z

Bedoya, P. A. (2014). The Exercise of Learner Autonomy in a Virtual EFL Course in Colombia. HOW Journal, 21(1), 82-102. https://doi.org/10.19183/10.19183/how.21.1.16

Budiharto, R. A., \& Amalia, L. (2019). Motivation Behind Indonesian Undergraduates Learning English As A Target Language. IDEAS: Journal on English Language Teaching and Learning, Linguistics and Literature, 7(1). https://doi.org/10.24256/ideas.v7i1.714

Chen, C.-H., \& Yang, Y.-C. (2019). Revisiting the effects of project-based learning on students' academic achievement: A meta-analysis investigating moderators. Educational Research Review, 26, 71-81. https:// doi.org/10.1016/j.edurev.2018.11.001

Creswell, J. W., \& Creswell, J. D. (2017). Research Design: Qualitative, Quantitative, and Mixed Methods Approaches. SAGE Publications.

Darsih, E. (2018). Fostering Language Learner Autonomy: Indonesian EFL Lecturers Voices. English Review: Journal of English Education, 7(1), 51-60. https://doi.org/10.25134/erjee.v7i1.1495

Farris, P. J., \& Werderich, D. E. (2019). Language Arts: Process, Product, and Assessment for Diverse Classrooms, Sixth Edition. Waveland Press.

Gholami, H. (2016). Self-Assessment and Learner Autonomy. Theory and Practice in Language Studies, 6(1), 46-51. https:/ / doi.org/10.17507/tpls.0601.06

Guo, P., Saab, N., Post, L. S., \& Admiraal, W. (2020). A review of project-based learning in higher education: Student outcomes and measures. International Journal of Educational Research, 102, 101586. 
https:// doi.org/10.1016/j.ijer.2020.101586

Hsieh, H.-C., \& Hsieh, H.-L. (2019). Undergraduates' Out-Of-Class Learning: Exploring EFL Students' Autonomous Learning Behaviors and Their Usage of Resources. Education Sciences, 9(3), 159. https://doi.org/10.3390/educsci9030159

Istifci, I. (2016). Perceptions of Turkish EFL Students on Online Language Learning Platforms and Blended Language Learning. Journal of Education and Learning, 6(1), 113. https://doi.org/10.5539/jel.v6n1p113

Koirala, S. (2020). Toward a negotiated autonomy: Culture, teaching perceptions, and participation of Bhutanese refugees in an adult migrant English program in Australia. TESOL Journal, 11(1). https:// doi.org/10.1002/tesj.460

Lengkanawati, N. S. (2017). Learner Autonomy in The Indonesian EFL Settings. Indonesian Journal of Applied Linguistics, 6(2), 222-231. https://doi.org/10.17509/ijal.v6i2.4847

Little, D. (2003). Learner autonomy and second/foreign language learning. In CIEL Language Support Network (Ed.), The Guide to Good Practice for Learning and Teaching in Languages, Linguistics and Area Studies.

Liu, G. (2016). A Study on the Autonomous Learning Validity of Chinese EFL Students. Journal of Language Teaching and Research, 7(4), 738. https://doi.org/10.17507/jltr.0704.14

Maarif, A. N. (2020). The Implementation of Peer Tutoring in Learning Reading for EFL Learners. JEEP (Journal of English Education Program), 7(1), Article 1. https://jurnal.unigal.ac.id/index.php/jeep/article/view/4311

Mangasi, P. L. (2019). Implementation of SQ3R to Increase Reading Interest, Critical Thinking Skills, and Ability to Understand Indonesian Language Reading of 6th Grade Indonesia A Students. International Journal of Theory and Application in Elementary and Secondary School Education, 1(1), 71-81. https://doi.org/10.31098/ijtaese.v1i1.10

Meddas, M. (2019). The Role of Peer Tutoring in Developing Middle School Pupils' Corrective Feedback: A Case Study of Fourth year Pupils at Mohamed Chaabani Middle School, Ouled Djellal [Thesis]. http://archives.univbiskra.dz:80/handle/123456789/14834

Morales, H. S., \& Mena, G. (2016). Student Self-Evaluation and Autonomy Development in EFL Learning. Revista de Lenguas Modernas, 199-222. https://doi.org/10.15517/rlm.v0i25.27695

Orawiwatnakul, W., \& Wichadee, S. (2017). An Investigation of Undergraduate Students' Beliefs about Autonomous Language Learning. International Journal of Instruction, 10(01), 117-132. https:/ / doi.org/10.12973/iji.2017.1018a

Otto, W. (2014). Reading Expository Material. Elsevier.

Rahman, Abd., \& Suharmoko. (2018). Building Autonomous Learners in English as a Foreign Language (EFL) Classroom. Proceedings of the International Conference on Education in Muslim Society (ICEMS 2017). International Conference on Education in Muslim Society (ICEMS 2017), Banten, Indonesia. https://doi.org/10.2991/icems-17.2018.44

Rice, S., Rizal, F., Yulastri, A., Riswandi, P., \& Hayadi, B. (2019). Application of The SQ3R Method to Improve Learning Motivation and Ability to Read English 
Text Understanding of it in Vocational High School of Ibnu Sina Batam. Proceeding of the 1st Workshop on Environmental Science, Society, and Technology, WESTECH. https:/ / doi.org/10.4108/eai.8-12-2018.2284030

Schmidt, N., \& Wehmeyer, H. (2016). Self-Assessment Training in The ESL Classroom: A Crucial Step in Developing Learner Autonomy. Journal of Second Language Acquisition and Teaching, 23(0), 74-97.

Shams, I. E. (2013). Hybrid Learning and Iranian EFL Learners' Autonomy in Vocabulary Learning. Procedia - Social and Behavioral Sciences, 93, 1587-1592. https:// doi.org/10.1016/j.sbspro.2013.10.086

Sholihah, I., Retnanindyah, P., \& Anam, S. (2019). Developing Autonomous Learners in Japan: Working with Teachers Through Professional Development. Jurnal $\begin{array}{lll}\text { Education } \quad \text { and 50 50 } & \text { 7(2), }\end{array}$ https://doi.org/10.37081/ed.v7i2.868

Suganya, S. (2019). The Effective Role of Reading Comprehension in Developing Communication through SQ3R Method (SSRN Scholarly Paper ID 3497334). Social Science Research Network. https:/ / doi.org/10.2139/ssrn.3497334

Sukhenko, O. (2019). Fostering Learner Autonomy: Self-evaluation in Enhancing English Writing Skills. Konteksty Pedagogiczne, 1(12). https://doi.org/10.19265/KP.2019.11253

Tayjasanant, C., \& Suraratdecha, S. (2016). Thai EFL Teachers and Learners' Beliefs and Readiness for Autonomous Learning. 3L The Southeast Asian Journal of English Language Studies, 22(3), 153-169. https://doi.org/10.17576/3L-20162203-11

Tharayil, S., Borrego, M., Prince, M., Nguyen, K. A., Shekhar, P., Finelli, C. J., \& Waters, C. (2018). Strategies to mitigate student resistance to active learning. International Journal of STEM Education, 5(1), 7. https://doi.org/10.1186/s40594-018-0102-y

Tight, M. (2017). Understanding Case Study Research: Small-scale Research with Meaning. SAGE.

Tran, T. Q. (2020). EFL students' attitudes towards learner autonomy in English vocabulary learning. English Language Teaching Educational Journal, 3(2), 86. https://doi.org/10.12928/eltej.v3i2.2361

Wiraningsih, P., \& Dewi, N. L. P. E. S. (2020). The roles of EFL Teachers in Promoting Learner Autonomy. Jurnal Pendidikan dan Pengajaran, 53(1), 13-24. https://doi.org/10.23887/jpp.v53i1.19241

Yuzulia, I. (2020). EFL Teachers' Perceptions and Strategies in Implementing Learner Autonomy. Linguists: Journal Of Linguistics and Language Teaching, 6(1), 3654. https:// doi.org/10.29300/ling.v6i1.2744

Zakaria, N., Aziz, A., \& Ramayah, K. (2017). Language Learning Strategies and Learner Autonomy in Learning Japanese. 50-60.

Zhou, Y., \& Chen, Y. (2020). A Study on Reticence in College EFL Classrooms: The Role of Diffusion of Responsibility. English Language Teaching, 13(6), 133-143.

Zouaidi, C., \& Hermessi, T. (2019). The Role of Intrinsic Motivation and Oral Corrective Feedback in the EFL Classroom. In S. Hidri (Ed.), English Language Teaching Research in the Middle East and North Africa (pp. 431-454). Springer International Publishing. https://doi.org/10.1007/978-3-319-98533-6_20 